Article

\title{
Towards East Asian Ecotheologies of Climate Crisis
}

\author{
Anna Kirkpatrick-Jung ${ }^{1}$ and Tanya Riches ${ }^{2, *(1)}$ \\ 1 Independent Researcher, 2016 Sydney, Australia; annakirkpatrick0307@gmail.com \\ 2 Hillsong College, 2153 Sydney, Australia \\ * Correspondence: tanya.riches@hillsong.com
}

Received: 31 May 2020; Accepted: 1 July 2020; Published: 9 July 2020

check for updates

\begin{abstract}
An anthropogenically caused climate crisis threatens the Earth and humanity. As such, religion's engagement is of increasing importance. This paper critically evaluates the significance of the East Asian context regarding the climate crisis, arguing for contextualization of contemporary ecotheology, or an East Asian contextual ecotheology. Considering how key contextual elements might inform ecotheologies to mobilize Christians regionally to action in relation to the climate crisis, this paper concludes that the field of East Asian ecotheology is an emerging conversation rich with opportunity for continued theologizing and inter-religious dialogue, and practical impetus for East Asian Christians to mobilize to address the climate crisis. Suggestions are made as to how these ecotheologies may be integrated into Christian practice in the region.
\end{abstract}

Keywords: climate action; ecotheology; ecological theology; contextual ecotheology; Asian theology

\section{Introduction}

Anthropogenically caused climate change has impacted ecosystems and human communities around the world, with continued greenhouse gas (GHG) emissions set to cause further global temperature rises, creating long-lasting impacts on our shared natural and human environments (IPCC 2014, p. 4; 2018a). Diverse, complex, and significant ecological issues contribute to the crisis but also are exacerbated by it (IPCC 2019b). While the IPCC urges rapid and unprecedented transformation of societies and economies globally, the current mitigation targets are deemed insufficient to limit global temperature increases (IPCC 2018a; United Nations 2018). Significantly, the IPCC states that regional and country-specific contexts affect responses to the crisis and its impacts due to a variety of contextual elements, and therefore, contextual addressing of the crisis is now required (IPCC 2019a, p. 3). Due to the scale of the crisis, a full community response is required, including from religious groups. This paper thus asks the question, "How might East Asian ecotheologies offer East Asian Christians a contextual theological basis with which to mobilize in address of the climate crisis?"

\section{Methods}

This paper synthesizes the literature in search of a contextual East Asian ecotheology suitable for regional mobilization in address of the climate crisis. It makes various suggestions based upon the findings of the literature review. It was originally presented as the first author's MA thesis at Hillsong College, ${ }^{1}$ the impetus for which emerged from and as an attempt to prepare for ministry in the East Asian context. Based from her previous study's focus on ecological concern, the topic of Christians

1 The first author would like to acknowledge Andrew Davies from the University of Birmingham for his external supervision of her MA thesis. 
undertaking ecologically beneficial outcomes from a theological basis emerged within her Masters degree, strengthened through work and church experience in the East Asian context.

Despite some recognition within the Christian tradition of the reality of the climate crisis and its implications, others tend to interpret these developments as a sign of end times, or reject climate change, its existence and implications entirely (Green 2014; John 2014; Ormerod and Clifton 2009, p. 71). However, rather than address the issue globally, the authors sought to contextualize factors and responses.

A scoping review was chosen as appropriate for preliminary topical content following Grant and Booth's (2009) recommendations. Initial searches intended to preference Pentecostal writings. However, as the scholarly resources originating within the Pentecostal tradition were few (and within this region even fewer), the field was widened to evangelical as well as other mainline Christian traditions. As Pentecostal theology often (by necessity or by purpose) draws upon wider Christian scholarship, this allowed for the broadening of the research to include these voices and perspectives. ${ }^{2}$ This is consistent with the approach to theology advocated by leading Pentecostal and Asian American scholar Amos Yong (2004) in which all the voices speak, and the spirit makes sense of the message to the hearer through points of consensus, as "consensual theology." In addition, from this literature, suggestions were made to inform praxis, contained herein. A focus upon pragmatic solutions is well understood as a Pentecostal trait (Wacker 2009).

Within this work, there is strong evidence for a shared geographic positioning, and precedent for the use of the term "East Asia" both in relation to religious-philosophical considerations and also approaches to environmental concerns (e.g., Diamond et al. 2015; K.-J. Kim 2010; 2017; Lam 2013; Liu 2006), although this paper critically assesses the notion of the East Asian context later. In order to assess the value of contextual ecotheology, the paper considered relevant all theology from the East Asian context, from cross-denominational Christian theologians, but ultimately focused upon three cases of mainland China, South Korea, and Japan.

\section{East Asia's Regional Significance within the Global Climate Crisis}

East Asia is a significant contributor to the global climate crisis as it has substantial and globally significant growing populations and economies. Such growth is historically shown to align with increased GHG emissions (The World Bank Group 2019a, 2019b). Already, East Asia's GHG emissions are globally significant, with China alone responsible for 55\% of carbon emissions since 1990 and the world's current leading GHG emitter (Zheng and Kahn 2017). Additionally, the region's rising middle class drives some unsustainable consumer habits, which increasingly align to those of more unsustainable developed markets (FAO 2013, p. 1; UN Environment 2016, p. 59). East Asia's current and projected consumer habits are inextricably linked with its projected population and economic growth, and therefore the ecologically detrimental impact of its consumption cannot be understated (The Economist 2018, 2019c; UN Environment 2016, p. 59). Nonetheless, concurrently, ecologically beneficial practices are increasingly being undertaken within the region. This includes ratification of international declarations and agreements, developments of national plans, emission reductions, increases in forest cover and significant investment into renewable resources (Hertsgaard 1997; Peterson 2018; The Economist 2019a; UN Environment 2016, p. 40, 2019; United Nations 2019; Zheng and Kahn 2017, p. 84). This indicates regional willingness to mobilize in address of the climate crisis, an important precedent that underpins this paper's question.

The East Asian demographic is globally significant in terms of its contribution to the climate crisis. ${ }^{3}$ Its population can be described as an "upside-down pyramid," which means that smaller, younger generations support its larger, older generations (Joo 2018, p. 402). East Asian governments, academics

2 Amos Yong (2004) articulates this rationale within Pentecostalism as "consensual theology" in which all the voices speak, and the spirit illuminates the message to the church.

3 As stated earlier, "East Asian" in this paper refers to transborder cross-denominational Christians of China, South Korea and Japan. All references to China in this paper are to the mainland. 
and multidisciplinary planning groups are taking this demographic trend into account (Chow 2018, p. 148; Joo 2018, p. 406; Lee and Minato 2015, p. 233). Therefore, it seems appropriate for East Asian ecotheology to do likewise by addressing the differing generational realities. The key socioeconomic elements include the region's rising middle class, increased consumer spending and practices shifting to those of more developed and ecologically unsustainable markets, and socioeconomic inequality (FAO 2013, p. 1; Joo 2018, p. 401; Lee and Minato 2015, p. 233; The Economist 2019b, 2019c; UN Environment 2016, p. 59). China's substantial population is rapidly developing-its substantial emergent middle class rose eightfold in consumer spending ${ }^{4}$ between 1990 and 2017. The nation is now the largest global market for passenger cars, smartphones and luxury goods (Lee and Minato 2015, p. 238; The World Bank Group 2019a). However, this trend is significant across all of East Asia, with regional changes including diet and fashion choices (FAO 2013, p. 1; Ellen MacArthur Foundation 2017; Global Fashion Agenda and The Boston Consulting Group 2017; UN Environment 2016, p. 59). This is despite Japan's growing consumer interest in sustainable consumption (perhaps due to economic pressures) and China demonstrating increased domestic pressure towards environmental protection (Assmann 2018, p. 64; Zheng and Kahn 2017, p. 82).

China is home to just under 1.4 billion persons, South Korea just over 51 million and Japan just over 126 million persons. (The World Bank Group 2019a). While dispute exists regarding the proportion of Christians within China and Japan (Kaiser 2015; Roemer 2009; Yung 2004), it can be estimated that Christians form approximately 5.1\% of the population in China (Pew Research Center 2019b), 29.4\% in South Korea (Pew Research Center 2019d) and 1.6\% in Japan (Pew Research Center 2019c). While Christianity may be proportionately low in China, it is still a regionally and globally significant population. Therefore arguably, opportunity exists to question the adoption of foreign consumption habits and to call for the development of a contextual theology relevant to everyday practice. Lastly, China is considered one of the most socioeconomically unequal countries globally with a debatably entrenched urban underclass, while South Korean and Japanese younger people face youth unemployment and job insecurity alongside social inequality (Joo 2018, p. 401; Lee and Minato 2015, p. 233). As such, opportunity exists for the development of contextual intersectional or liberationist ecotheologies which may redress this inequality. As Christianity is a minority religion within each of these national contexts (Pew Research Center 2019b, 2019c, 2019d), this selection of transborder and cross-denominational Christians also enables engagement with the largest possible group of East Asian Christians in order to suggest the greatest potential for impact on practice. Additionally, given Christianity's minority status within East Asia, this arguably contributes towards the potential (or need for) public engagement including interfaith dialogue with greater contextual relevance upon climate impacting practices.

\section{A Consideration of "Ecotheology"}

A succinct critical consideration of ecotheology, its emergence and contemporary approaches are provided in this section as a foundational framework. Ecotheologies emerged from the mid-20th century, reflective of an increase in environmental awareness and concern. Therefore, many early ecotheologies were apologetic in nature, which resulted in them having an anthropocentric or "stewardship" environmental ethic (Deane-Drummond 2008, p. x; Scoville 2000, p. 58; Troster 2013, p. 381; Yong 2010, p. 343). In contrast to this, Paul Santmire, one of the earliest Christian ecotheologians, defined ecotheology as a "theological discourse that highlights the whole 'household' of God's creation, especially the world of nature, as an interrelated system" (Santmire in Troster 2013, p. 382). Importantly, Rabbi Lawrence Troster (2013, p. 382), who writes from a Jewish perspective, highlighted the importance of integrating scientific understanding of the natural world together with traditional theologies; which inevitably produces a new theological paradigm. Deane-Drummond (2008, p. xii) asserted that ecotheology "seeks to uncover the theological basis for a proper relationship between

4 In inflation-adjusted terms. 
God, humanity and the cosmos," while Tucker (in Troster 2013, p. 383) proposed that it transforms traditional theology through retrieval, reinterpretation and reconstruction. This results in a more "planetary expression" (Tucker in Troster 2013, p. 384).

Troster (2013, p. 382) claims that the approach that was to become ecotheology was first presented in Haught's 1993 identification of the emergence of a sacramental approach to the growing ecological crisis, that emphasized natural revelation and which argued that tradition must theologize in response to scientific knowledge. Today, ecotheology is considered an important part of Christian systematics (and theology more broadly). As such, it appears in many theological works commonly used amongst Pentecostal-evangelicals (Migliore 2014, p. 96; Moltmann 1993a, 1993b, p. 19; Pannenberg 1994a, p. 1; 1994b, p. 586). However, as it interprets scripture and tradition through its particular ecological lens, Spencer (2015, p. 415) argues that it can be considered a contextual theology. As a result of its emergence from the land, ecotheology can also be understood as a non-Western theology (Kärkkäinen 2003, p. 187). Given the increased global public attention on the climate crisis and ecological concerns (Feldman 2019; Flannery 2019; Taylor 2019a), ecotheology continues to provide opportunity for outreach via engagement with the public, and operates as the basis for interfaith work.

Following the scope of the literature, a number of contemporary approaches to ecotheology are considered here. This includes two biblical theology approaches, four constructive theology approaches and a practical theology approach. This list is not comprehensive but representative of global ecotheologies today. ${ }^{5}$

The two biblical approaches to ecotheology might be termed "biblical ecotheology" and "ecological hermeneutics". The first category, biblical ecotheology, engages the biblical texts across the canonical Old Testament and New Testament scriptures as well as non-canonical scriptural writings that have evident ecological themes (e.g., Balabanski 2008; Deane-Drummond 2008, p. 81; Howard 2008; Marlow 2008; S. Miller 2008; Swenson 2008). In contrast, the second category of ecological hermeneutics invites interpreters to read these biblical texts through an ecological lens: e.g., the Earth Bible project which invites ecological readings of scripture through six ecojustice principles; or Habel's (2008) invitation for ecological readings through a hermeneutic of suspicion, identification and retrieval. These approaches are not without critique, as for example, Deane-Drummond $(2008$, p. 92) rejects their emphasis on the subjectivity of creation.

Constructive ecotheology approaches are useful due to their orientation away from anthropocentrism; instead, they emphasize biodiversity, the integration of science and praxis. The first category is interconnected approaches: holism (including Leopold's land ethic), deep ecology (Deane-Drummond 2008, p. 32; Scoville 2000, p. 59) and Berry's (2003) creation spirituality, which despite being most appropriately understood as philosophically rather than theologically based, are included here. Second, the work of Troster (2013, p. 382) draws on medieval Jewish theologian Maimonides to integrate understandings relevant to the science-theology field. Despite popular belief that the science-theology relationship is marked by "unremitting conflict" (Barrett 2013, p. 41), the expanding science-theology field has argued for and demonstrated this integration over the past five decades (Barrett 2013, p. 34; Kracher 2000, p. 486; Migliore 2014, p. 117; Mooney in Barrett 2013, p. 38; Pannenberg 1994b, p. 1). Liu Xiaofeng argues that an ontic integration would engage the broader Chinese atheistic worldview (in Chow 2018, p. 78). Indeed, such integration seems appropriate within contemporary ecotheology, given ecotheology's cosmic scope and the significance of the climate crisis. A third useful approach tends to refer to the Colossians 1:15-20 hymn, drawing attention to an all-encompassing cosmic Christology, with Christ as the one through and for whom

5 For example, animal theologies and ethics (e.g., Clough 2012, 2019) and liberationist ecotheologies (e.g., Boff 1997) are not included in this paper's scope as the study sought constructive approaches most relevant to an East Asian ecotheology. The applications that were found for East Asian ecotheology, which assisted in determining this relevance, centered more on the categories as listed here. However, other approaches to ecotheology, including these two categories, could also be explored in relation to East Asian ecotheology and praxis as an extension of this study. 
all creation was made, and which therefore points forward to the reconciliation and redemption of all (Deane-Drummond 2008, p. 100). Examples include work by Sittler (in Lam 2013, p. 223), Moltmann (1993c, p. 275, 2012, p. 138) and Fox (1988, p. 35). Finally, pneumatological approaches are a useful constructive approach to ecotheology (particularly cosmic-centric or theocentric, as opposed to traditional anthropocentric). Pneumatological approaches to ecotheology have increased since the 1980s, and include notable works by Bergman, Bulgakov, Edwards, Wallace, Johnson, Moltmann (1993a), Deane-Drummond (2008, p. 130) and Yong (2010, p. 343). Additionally, Deane-Drummond (2008, p. 144) notes the potential of pneumatological approaches in relation to ecological praxis, while Yong (2010) identifies their contribution to political ecotheologies. Both Yong (2010, p. 344) and Kärkkäinen (2002, p. 171) give an example of charismatic movements in the global south leading in liberative ecological praxis.

Lastly, Schreiter (2015, p. 106) scopes an ecotheology of praxis-with interdependent theoretical and practical aspects. Ecotheology is vitally connected to environmental practice, including climate justice, ethics and related practices, (Deane-Drummond 2008, p. 179; Ormerod and Clifton 2009, p. 70) to the extent that Deane-Drummond (2008, p. 178) states ecological ethics could be regarded as the "beginning and end of eco-theological reflection" as initial concerns often motivate ecotheological reflection and such reflection tends to end with theological rationales for specific ecological practices (Also Scoville 2000, p. 58; Troster 2013, p. 381; Yong 2010, p. 343). Such understanding finds precedent within the work of Deane-Drummond (2008), Moltmann (1993a, p. 1) and Bock (2016, p. 9).

\section{Why Contextualize Ecotheology?}

This paper now turns to critically consider the proposal of the formation of a contextual ecotheology, which may be suitable for a regional area such as East Asia. Contextualization is generally considered a vital theological process that aims to make scripture intelligible, relevant and applicable to a contemporary cultural context (Bevans 2002, p. 3; Erickson 2013, p. 68; Grenz 2000, p. 12). Contextualization usually includes consultation of a range of sources that may inform belief. While affirming scripture, theologians contextualize in various ways: listening to the changing culture in context; avoiding introduced paternalistic prescriptions of traditional theologies; considering the relativity of objective truths and/or the subjectivity of the interpreter in a particular historio-cultural milieu (Bevans 2002, p. 3; Erickson 2013, p. 68; Grenz 2000, p. 14). Unlike traditional theologies that have tended to be implicitly contextual, contextual theologies are explicitly contextual. From the early 1970s, contextual theologies and hermeneutics with a strong praxis orientation emphasizing the interpreter's context emerged as specific lenses through which to interpret within Latin America, Africa and Asia, as well as from “Western" subcontexts (Kärkkäinen 2004, p. 10; Moltmann 2000, p. 183; Schreiter 2015, p. 105; Wolcott 2016a, 2016b). While different definitions, forms and approaches exist, the distinctive feature of contextualization is its understanding of the subjectivity of all interpreters and theology, in contrast to traditional and modernist claims that interpreters and theology are objective (Bauckham 1998, p. 7; Bevans 2002, p. 4; Holtzen and Nelson Hill 2016, p. 90; Moltmann 2000, p. 183; Schreiter 2015, p. 1; Tanchanpongs 2015, p. 100).

Despite the general acknowledgement that classical theologies and creeds were contextually influenced, the term contextual theology is typically more applied to non-Western theologies (Bevans 2002, p. 5; Kärkkäinen 2003, p. 187). Theology in most contexts, therefore, is by default generally white, affluent and typically male in its location or "norm." The exclusion of dominant or Western theologies relegates contextual theologies as non-normative, marginal or "other." This is often critiqued. The need for culturally diverse, contemporary theologies increases with the diversification of the church itself (Erickson 2013, p. 70). At the dawn of the third millennium, the typical Christian was a non-white, non-affluent, non-northern and female person and by 2050, it is projected that four-fifths of global Christianity will be non-white (Kärkkäinen 2004, p. 241). Thus, Lee (in Kärkkäinen 2004, p. 242) emphasizes that contextual Asian theologies are not subsidiary or supplemental to Western theologies, while Conradie, Kim and Koster suggest that contextual ecotheologies should decenter the dominant 
north Atlantic Christian "norm" (Jenkins et al. 2018, p. 94). Other challenges of contextual theology are important, including the oft-cited risk of context being imposed above scripture and tradition (e.g., Spencer 2015, p. 421; Tanchanpongs 2015, p. 110), but due to the climate crisis, this is secondary to the threat now facing human life. Given this threat, together with the IPCC's (2019a, p. 3) determination that it is appropriate and important to address the climate crisis contextually, it is reasonable to assert that the development and recognition of contextual ecotheologies is paramount. It is in light of these considerations that the paper asserts the importance of all contextual ecotheologies, including an East Asian ecotheology.

Contextual ecotheology has mostly emerged in the past decade, although examples are evident from the late 20th century onwards. Although an emerging field, it is highly significant. As mentioned, ecotheology can already arguably be understood as a contextual and non-Western theology, and therefore the desire here is for further contextualization into a particular historical-cultural context or subcontext. Despite the lack of definition to the term "contextual ecotheology" in current literature, a multitude of examples can be considered including those from North and Central America (Ahn 2015; O'Brien 2012; Rieger 2004), South America (Boff 1997), Europe (Anker 2013; Kjellberg 2004), the Middle East (Awad 2016), Africa (Agyarko 2013; Conradie 2009; Lugazia 2016; Nwaigbo 2011; Okonkwo 2011) and the Asia-Pacific region (Chung 2016; Hong 2013; Hwang 2007; H.Y. Kim 2017; K.-J. Kim 2010; Y.-B. Kim 2005; Kwara 2014; Lai 2014; Oh 2016). Examples of both confessional and constructive ecotheologies are present from within various Christian traditions and contexts including Catholic, Lutheran, Wesleyan, evangelical, Pentecostal, liberationist, feminist, womanist and indigenous perspectives (Deane-Drummond 2008, p. 46; Jenkins et al. 2018, p. 93; Yong 2010, p. 344).

Interfaith ecological explorations are also in progress, including Christian dialogue with traditional religions (e.g., Okonkwo 2011 in Africa), as well as Buddhist (Ahern 2006; K.-J. Kim 2010; Lai 2006), Confucian (K.-J. Kim 2010; Lai 2014) and Daoist (H.Y. Kim 2017; Lai 2014) traditions. These examples are selected as regionally significant for East Asia. Nevertheless, the typical disagreement regarding the climate crisis is not typically between religious traditions, but within religious traditions in different locations (Jenkins et al. 2018, p. 94). Perhaps this is unsurprising given the differences between cultural contexts globally. This is demonstrated amongst evangelicals in the USA versus the rest of the world, and between Christianity of the global south and north (Jenkins et al. 2018, p. 94). Thus, the challenge for contextual ecotheologies is to find commonality despite diversity. In response, this paper explores a shared East Asian ecotheology inclusive of three national cases that will share commonalities while recognizing distinctives.

\section{An East Asian Contextual Ecotheology?}

To form a framework for this paper's later critical examination and assessment of the possibility for an East Asian ecotheology, key contextual elements are now proposed.

Given the enormous diversity within the region, a key relevant challenge for Asian contextual ecotheology is how to identify a "critical Asian principle," that is, distinctively Asian content or method relevant for theological undertakings (Kärkkäinen 2003, p. 267; Kwan 2014, p. 41). Indeed, Kwan (2014, p. 30) argues that the term "Asian" is a prominent and persistent challenge. He advocates that its binarism must be unmasked and deconstructed, as otherwise, colonial ideology is unintentionally re-inscribed via Asian theological discourse (Kwan 2014, p. 30). Consequently, postcolonial theory has been significant within Asian theologies-implicitly since the mid-1990s but explicit more recently (Kwan 2014, p. 9). Looking at Asian theologies today, arguably two communities have developed: one closely engaged with Latin American or developing world liberation theologies, and another that is explicitly anti-missionary (Kwan 2014, p. 54). However, Kwan (2014, p. 59) argues that a theology defined in opposition to the "West" is ultimately still defined by and in recourse to the "West". Therefore, any Asian ecotheologies must avoid being defined by the "West" and thereby relegated as subsidiary, supplemental, on the margins or "other". In contrast, Song encourages Asian theologians to write "third-eye" theology "from the womb of Asia", the term "third-eye" being a reference to 
the Buddhist master who opens eyes to see areas previously unknown (Kärkkäinen 2003, p. 266). While this does not define what is distinctively Asian, it can certainly be understood as encouragement for more Asians authoring contextual ecotheologies, and for Asian ecotheologies to be informed by their indigenous contextual resources. Of course, in furthering Kwan's (2014) proposal, East Asian ecotheologies might draw upon Western ecotheologies not in opposition to them, but rather, in parallel.

Clearly, it is first appropriate for a contextual ecotheology to examine and assess its geographically based ecological context. Ecotheologies often highlight the importance of story and place in their formation (Spencer 2015, p. 416). Therefore, a contextual ecotheology is even further contextualized to its particular historical-cultural context or subcontext. Schreiter $(2015$, p. 49) argues that the theologian should first study the context before any translation, and should be holistic to avoid reductionism. It seems reasonably ambitious yet feasible to suggest that particular contextual elements (ecological, demographic, socioeconomic, cultural, political, economic and religious-philosophical) should be examined and assessed, with allowance for varying emphases depending on the context and the interpreters' agenda. Once this has been undertaken, contextual ecotheological understandings and practices can be proposed. Therefore, this is a consideration of the geography itself; East Asia's ecological issues across land, waste, water and air are diverse, complex, significant and often interrelated with the climate crisis, both as contributing factors to and effects of the crisis (UN Environment 2016). Additionally, as noted earlier, the region is projected to suffer from more natural disasters and extreme weather due to the climate crisis, with substantial ecological and human cost (IPCC 2014, p. 7; Lee and Minato 2015, p. 240; Mcateer 2012; Taylor 2019b; UN Environment 2016, p. 28).

Next, socio-cultural influences relevant to this paper's question are now examined and assessed. There is a close connection between economic growth, competitiveness and political agendas in East Asia, as well as the previously highlighted alignment between economic growth and ecologically detrimental practices, which is amplified due to East Asia's substantial and growing population, particularly in China (Bae 2013, p. 759; Chow 2018, p. 138; Chun et al. 2007, p. 548; Diamond et al. 2015, p. 407; Hertsgaard 1997; Lee and Minato 2015, p. 245; J. Miller 2013, p. 249; Peterson 2018; The Economist 2012, 2018, 2019a, 2019b, 2019c; The World Bank Group 2019a; UN Environment 2016, p. 40; United Nations 2019; Zheng and Kahn 2017, p. 82; Zhuang 2017). Additionally, the complexity and pressure for urban development has demonstrably produced negative ecological and social impacts across East Asia (Lee and Minato 2015, p. 229). Concurrently, however, examples are present within East Asia of how new technologies and initiatives could support sustainable urban and economic growth through transborder intercity learning and address of shared challenges (Lee and Minato 2015, p. 257; van Dijk 2011, p. 31). Drawing on earlier discussion, here a transborder civil society, in which local churches play a role, and ecological praxis centered on urban development may best align with the region (Bae 2013, p. 759; Chun et al. 2007, p. 548; Diamond et al. 2015, p. 407; Hertsgaard 1997; Lee and Minato 2015, p. 245; J. Miller 2013, p. 262; Peterson 2018; The Economist 2019a, 2019b, 2019c; UN Environment 2019, p. 11; United Nations 2019). It is here worth noting that women disproportionately outnumber men within the Chinese Christian demography (Chow 2018, p. 152). Despite being under-represented within East Asian politics, women have achieved prominent political, bureaucratic and NGO positions within the environmental sector (Schreurs 2001, p. 63). As such, Chinese Christian women who can find a way forward into leadership positions in the Chinese and East Asian environmental sector might be able to build relationships and achieve positive ecological impact with Chinese and East Asian governments and civil society. Within South Korea and Japan, the younger generations have demonstrated capacity for street activism and despite various differences also do share commonalities, including the use of digital media, connection to youth cultures and disagreement with governments or aspects of society (Joo 2018). This capacity for leadership and advocacy suggests opportunity and need for socio-ecotheologies or eco-feminist/womanist theologies that can enable Christian practitioners within these demographic groups to not only theologize and engage in ecological praxis independently but also to build relationships for collaboration with their local and transborder civil society and for political influence with their central and local governments for greater ecological 
impact. This evidence of civil society's ability to collaborate transborder demonstrates potential for how a shared ecotheology and praxis might operate through the efforts of Christian scholars, church leaders and practitioners within their local civil society. Despite historic and contemporary disputes or tensions between the three nations under consideration, an East Asian transborder civil society may play a significant role within transborder ecological dialogue and praxis (Chung and Kim 2016, p. 124; Diamond et al. 2015, p. 393; The Economist 2010, 2019c). There is great potential for agreement on the significance of shared problems and the implementation of solutions (Chung and Kim 2016, p. 124; Diamond et al. 2015, p. 397; The Economist 2019c). Additionally, a demonstrated capacity for East Asian transborder civil society collaboration, particularly across urban contexts, again reinforces the potential and need for a shared East Asian ecotheology.

However, this concurrently demonstrates the need for national case-based differentiation within any shared East Asian ecotheology; while activism is evident and significant within South Korea and Japan, it is not appropriate for the Chinese case. Differing components in each nation demonstrate support for case-based praxis, particularly responding to political governance and economic growth over the past thirty years. For example, despite China's increasing demand on resources and their ecologically detrimental practices, its local and central governments have undertaken more ecologically beneficial practices, albeit to promote their nationalistic agenda of economic competitiveness (Hertsgaard 1997; Lee and Minato 2015, p. 245; J. Miller 2013, p. 262; Peterson 2018; The Economist 2019a, 2019b, 2019c; UN Environment 2016, p. 40, 2019, p. 11; United Nations 2019; Zheng and Kahn 2017, p. 84). Therefore, opportunity exists for ecological praxis resulting in economic benefits to be adopted by local and central Chinese government. By identification of, promotion of or engagement in such practices, Chinese Christians might build mutually beneficial relationships with local and central government. In South Korea, however, under an increasingly decentralized governance style, local governments have undertaken ecologically beneficial practices, arguably to improve their city's image as measured against other global parties (Bae 2013, p. 759; Chun et al. 2007, p. 548; The Economist 2019a; UN Environment 2016, p. 63, 2019, p. 11; United Nations 2019). This provides opportunity for ecological praxis resulting in image-boosting effects for local cities to be adopted by local South Korean government. As such, by identification of, promotion of or engagement in such practices, South Korean Christians might build mutually beneficial relationships with local city-based governments. However, in Japan, in response to the central government's largely ineffective responses to ecological emergencies, Japanese local government, working alongside local civil society, has adopted an improvised, decentralized and bottom-up approach to addressing such emergencies (Bae 2013, p. 759; Chun et al. 2007, p. 548; Diamond et al. 2015, p. 407; The Economist 2019a; UN Environment 2016, p. 21, 2019, p. 11; United Nations 2019). This demonstrates a way forward for the relationship that might be developed between local Japanese government and local churches in collaboration with local civil society in address of ecological emergencies. This is noteworthy given the projected increase in natural disasters and extreme weather events in East Asia due to the climate crisis (IPCC 2014, p. 7; Lee and Minato 2015, p. 240; Mcateer 2012; UN Environment 2016, 2018). Thus, a shared East Asian ecotheology needs to make room for such differentiations-therefore, within China, it may emphasize the economic benefits of ecological praxis in alignment with both local and central government, while in South Korea, it might emphasize image-boosting benefits of localized praxis in alignment with local government, and in Japan, it might emphasize collaborations between local government and civil society, in which local churches play a role, in emergency responses to increasing and worsening natural disasters.

\section{Importance of the East Asian Religious-Philosophical Context}

This section examines and assesses key elements of the East Asian religious-philosophical context, but particularly those most relevant in forming an East Asian Christian ecotheology in address of the climate crisis. It does not intend to provide a comprehensive view or comparative study of these traditions. Christianity has a minority status within East Asia and therefore limited influence in this 
region. Drawing upon earlier discussions, as posited by Kwan (2014, p. 59), it is important to define East Asian ecotheology without definition by and resource to the "West". Indeed, J. Miller (2013, p. 251) argues that Asian traditions are often "othered" regarding contemporary ecological challenges when their values are assumed to be in opposition to Western modernity. This binarism results in uncritical, narrow or simplistic conclusions being drawn. In contrast, Song's encouragement is for Asian theologians to write "third-eye" theology "from the womb of Asia" (Kärkkäinen 2003, p. 266), and East Asian ecotheology is encouraged to strongly emphasize its cultural and religious-philosophical context and draw on indigenous resources. As such, this paper seeks to highlight some relevant features of indigenous or deeply embedded religious-philosophical resources. However, Lancaster (1997, p. 8) provides strong warning regarding the rejection of ordinary religious-based cultural practices in favor of any tradition's texts, citing examples of Sri Lankan Buddhism. Therefore, the authors are wary of drawing too much attention to East Asian religious-philosophical textual canons, theological essences or histories while neglecting ordinary contemporary practices. As such, within the paper's limited constraints, it here reviews features of East Asia's broader religio-philosophical context that may situate this contextual discussion, despite its audience being largely East Asia's Christians.

For this examination and assessment, it is important to first note that within the religio-philosophical context of East Asia, a plurality of ecological perspectives exist (Lai 2014, p. 87). Indeed, Lai (2014, p. 85) considers calls for this plurality to inform the process, advocating mutual learning and transformation rather than any attempt to form a universal ecological ethic. This takes into account the magnitude of the ecological crisis and the strong influence of a person's religion upon their praxis. East Asia's syncretistic nature is noted in China from the 4th century BCE, mostly between the "three teachings" of Confucianism, Daoism and Buddhism. The religious teachers and their associated ideas, dialogues, identities and cultures later spread to the Korean and Japanese contexts, although not without some tension (Chang and Kalmanson 2011, p. 222; Chow 2018, p. 15; Chung 2010, p. 269; K.-J. Kim 2010, p. 88; Paracka 2012, p. 89). This syncretism does not incline towards relativism, however, but pragmatism, as each tradition is absolutist, or biased against foreign religions. A syncretistic coexistence must be carefully undertaken as the result is sometimes disastrous (Chung 2010, p. 273; Lai 2014, p. 88; Paracka 2012, p. 89). However, strong support and also need for interfaith ecotheological dialogue creates an impetus.

Confucianism arguably represents the most distinct religious-philosophical element of East Asia, and is implicitly, if not explicitly, the leading East Asian paradigm (Chang and Kalmanson 2011, p. 215; Chow 2018, p. 2; Chung 2010, p. 270; H.Y. Kim 2017, p. 59; K.-J. Kim 2010, p. 293; Lam 2013, p. 227; Liu 2006, p. 26; Xiangchen 2010, p. 181). Strong precedent and examples of Christian-Confucian ecotheological dialogue exists, but notable is the work of K.-J. Kim (2010) and Lam (2013, p. 226). Indigenous to China, Confucianism's anthropocosmic worldview promotes unity within the trinity of Heaven, Earth and humanity, with humanity incurring a filial indebtedness to Heaven and Earth (Chang and Kalmanson 2011, p. 222; Chow 2018, p. 135; J. Miller 2013, p. 249; Weiming 2001, p. 243; Zhang in Weiming 2001, p. 245). As Weiming (2001, p. 247) notes, prior to Western influence, "Confucian humanism largely defined political ideology, social ethics, and family values in East Asia." Its teaching accentuates cosmic harmony that rests upon active self-cultivation through concentric circles of influence to the broader world, beginning with one's family and continuing outwards through community, society, government and eventually the entire cosmos (Chan in Chow 2018, p. 136; Chow 2018, p. 146; Kalton 2011, p. 205; Lai 2014, p. 88; Lam 2013, p. 227; J. Miller 2013, p. 250; Weiming 2001, p. 248; Xiangchen 2010, p. 181). Together, these understandings transform human desire to conquer nature, as humans act both as citizens of human society and citizens of Heaven. Humanity's moral mandate and highest accomplishment is bringing Heaven's way into the world through self-cultivation which results in a harmonious flourishing world for both humans and the natural environment (Chow 2018, p. 137; Kalton 2011, p. 195; Lai 2014, p. 90; Lam 2013, p. 227; Liu 2006, p. 34; Paracka 2012, p. 81; Weiming 2001, p. 249; Xiangchen 2010, p. 181). These aspects hold substantial potential as an indigenous resource for informing East Asian ecotheology and praxis (Kalton 2011, 
p. 192; K.-J. Kim 2010, p. 297; Lai 2014, p. 88; Lam 2013, p. 227; Liu 2006, p. 26; Weiming 2001, p. 254; Xiangchen 2010, p. 187). Other scholars note that the Cosmic Christ, the doctrine of creation's view of nature, the Incarnation and biblical themes of social and ecological justice also hold potential for interfaith ecotheological dialogue (Chow 2018, Xiangchen 2010, p. 182). Additionally, Confucianism, along with Daoism and Buddhism, holds a particular recognition of natural sites in religious-philosophical terms (Paracka 2012, p. 82). This creates opportunity for interfaith ecotheological dialogue and praxis centered on significant ecological sites. Other Confucian elements translate well to ecological ethics, and clearly, Confucianism within East Asia possesses substantial indigenous resources to inform East Asian ecotheology and praxis in address of the climate crisis.

Daoism, which is older than Confucianism, but also indigenous to China, is sometimes considered "the root of Chinese culture" and is prominent across East Asia. Alongside Confucianism, it is representative of the most distinct elements of the East Asian religious-philosophical context (Chow 2018, p. 2; K.-J. Kim 2010; Lam 2013, p. 226; Xiangchen 2010, p. 182). Daoism shares some commonalities with Confucianism and Buddhism including the anthropocosmic worldview, humanism and cosmology (Chow 2018, p. 86; Kalton 2011, p. 198; H.Y. Kim 2017, p. 59; K.-J. Kim 2010, p. 297; Lai 2014, p. 88; Lam 2013, p. 227; Liu 2006, p. 26; J. Miller 2013, p. 249; Weiming 2001, p. 260). However, unlike Confucianism, both Daoism and Buddhism tend to affirm non-differentiated benevolence to all living (or at least sentient) things due to a strong emphasis on mutual interconnectedness and equality (Y.-B. Kim 2005, p. 169; Lai 2014, p. 88; Xiangchen 2010, p. 182). This also suggests a potential limitation on the resourcefulness of these traditions for ecological understandings and praxis if differentiation between phenomena or species is required. Nevertheless, Paracka $(2012$, p. 76) suggests that Daoism distinguishes itself from Confucianism and Buddhism through its emphasis on Earth, balance, health, ecology and longevity. Daoism holds distinct cosmological understandings resulting in its core values of naturalness and nonassertive action (H.Y. Kim 2017, p. 42; Y.-B. Kim 2005, p. 169; Lai 2014, p. 90; J. Miller 2013, p. 225). Arguably, this emphasis on non-intervention or non-violation of natural processes in the natural world might indicate another potential limitation on its use as a resource for ecological praxis, however, in light of the anthropogenically caused climate crisis, it might also be engaged with as a strength. Certainly, environmental protection can here be emphasized as an ecologically beneficial precept and is found in Daoism's core texts (J. Miller 2013, p. 255). Indeed, within the contemporary Chinese context, Daoism engages in environmental protection of specific sites related to particular religious practices, partially in alignment with the government's nationalistic agenda (J. Miller 2013, p. 257). This suggests opportunity for continuing interfaith dialogue and praxis centered on these specific sites via a Chinese but also shared East Asian ecotheology, given Daoism's regional influence. Again, there are various examples of a Christian-Daoist ecotheological dialogue, but notably, H.Y. Kim's (2017) fascinating proposal of the construction of a new paradigm of theology that shifts the root-metaphor of Western logos and praxis to the Dao resulting in the "theodao", and an emphasis on a pneumatosocosmic narrative of the underside within creation that expands the notion of minjung pneumatologically and ecologically (H.Y. Kim 2017; Lam 2013, p. 226). There is arguably potential for Daoism not only to inform ecotheology and praxis regionally but also globally. Overall, while J. Miller (2013, p. 251) notes that Western perspectives of Daoism tend to be simplistically uncritical or narrow, which negate the role that Daoist ideas can play in today's ecological challenges, this paper rather asserts that Daoism within East Asia possesses both a substantial indigenous resource as well as some possible limitations for informing an East Asian ecotheology and praxis in address of the climate crisis.

Buddhism, which was introduced to China from India as a foreign religion almost two millennia ago, has undergone a considerable process of acculturation and syncretization, but has mostly existed in peace alongside Confucianism and Daoism, and today is arguably considered one of the leading East Asian paradigms, predominantly through the Mahayana Buddhist tradition (Chang and Kalmanson 2011, p. 215; Chow 2018, p. 15; Chung 2010, p. 274; Habito 2003, p. 364; H.Y. Kim 2017, p. 59; K.-J. Kim 2010, p. 293; Lai 2014, p. 88; Paracka 2012, p. 89; Parkes 1997, p. 113). Its current and projected influence in contemporary East Asia is evident (Pew Research Center 2019a). Unsurprisingly, 
Buddhism shares various commonalities with Confucianism and Daoism. However, it also possesses distinctives that may inform East Asian ecotheology and praxis in address of the climate crisis. Despite Buddhism having been praised for its ecologically beneficial way of life, diverse perspectives exist (Ahern 2006, p. 227; Lai 2006, p. 184; Lai 2014, p. 88; Lancaster 1997, p. 11; J. Miller 2013, p. 251; Rots 2017, p. 48; Sponberg 1997, p. 351; Xiangchen 2010, p. 182). Assisting in categorization, Swearer (2006) proposes recognition of five positions within Buddhism: eco-apologists, eco-critics, eco-constructivists, eco-ethicists and eco-contextualists. Numerous Buddhist doctrines are noteworthy, including the universal Buddha nature and the doctrine of dependent co-arising which support a nondualistic and holistic worldview where all sentient beings, if not all phenomena within the cosmos, are mutually interconnected but interdependent (Ahern 2006, p. 225; K.-J. Kim 2010, p. 293; Lai 2004, p. 213; Lai 2006, p. 199; Lancaster 1997, p. 13; Parkes 1997, p. 113; Sponberg 1997, p. 374). This understanding is well articulated in the Hua-yen subtradition of Mahayana Buddhism through its notion "one-in-all and all-in-one", which together with its concept of the "Pure Land" result in this subtradition being ascribed as holding particular ecological resources (Ahern 2006, p. 225; K.-J. Kim 2010, p. 293; Lai 2004, p. 217; Lai 2006, p. 203; Sponberg 1997, p. 374; Swearer 2006, p. 125). Additionally, as support for Buddhist ecological praxis exists, there seems to be distinct opportunity for interfaith ecological praxis amongst business practitioners, particularly significant given the alignment between economic growth and ecological destruction (Lancaster 1997, p. 9; Swearer 2006, p. 126). Diverse approaches to engagement in Christian-Buddhist ecotheological dialogue have precedent; other scholars note that correlations between perichoresis and anakephalaoiōsis could enrich systematics (Ahern 2006; Habito 2003; K.-J. Kim 2010; Y.-B. Kim 2005; Lai 2004, p. 220, 2006; Lam 2013, p. 226). Overall, this paper asserts that Buddhism, but particularly Mahayana Buddhism which is found across East Asia, holds both potential opportunities and limitations for informing a regional East Asian ecotheology and praxis in address of the climate crisis. There may also be other distinct understandings from Korean and Japanese Buddhism that could inform ecological praxis (Habito 2003, p. 363; Y.-B. Kim 2005, p. 171; Parkes 1997, p. 113).

This paper now turns to distinct religious-philosophical insights from its three national cases. In the South Korean case, shamanism brings a distinct contribution. Evident as a belief system in various forms around the world, shamanism can be understood within the Korean context as a dualistic concept in which humanity relates through highly personalized, emotional, dynamic exchanges or alliances via shamans with supernatural beings that govern the natural world (Chung 2010, p. 270; Walraven 2009, p. 75). Observably, traditional and contemporary Korean shamanism differs greatly (Walraven 2009, p. 76). Nonetheless, some scholars suggest that Pentecostalism's success in South Korea has been partially due to its integration of shamanism, despite its leaders denying this integration (Anderson 2000, p. 130). Further, the prayer mountain movement, a distinct feature of South Korean Christianity more broadly, aligns well with indigenous shamanistic understandings of mountains as places of spiritual retreat and pilgrimage, where both shamans and ordinary persons receive power from spirits (Anderson 2000, p. 125). Mountains are also highly regarded within the three teachings inherited from China into the Korean context (Chung 2010, p. 269; Paracka 2012, p. 82), thus it seems reasonable to suggest that these three teachings alongside shamanism may also have been influential in informing distinctly South Korean Christian practice (Anderson 2000, p. 127). Such understandings could inform a South Korean ecotheology and praxis, resulting, for example, in interfaith ecotheological dialogue and praxis centered on greater environmental protection of mountain sites for multifaith religious understandings and practices, as well as the role of personalized and active religious practices. Given that mountains cover approximately $70 \%$ of the nation, this is highly relevant (Choe et al. 2018, p. 3). Therefore, this paper asserts that South Korean shamanism may hold significant potential for informing a South Korean ecotheology and praxis in address of the climate crisis.

Additionally, there are particular syncretistic understandings worth highlighting in the South Korean case that bring a further distinct contribution. The historic suffering under foreign and national oppressive powers combined with Confucian understandings of a Great Peace and Prosperous Age 
being established in the land, as well as Daoist understandings of Korea as the Land of Divine Angelic Beings, Buddhist understandings of Korea as the Western Pure Land, and Tonghak understandings of Korea as the land of the Second Creation developed into syncretistic understandings of the land of the Korean Peninsula in support of the establishment of a utopian vision (Y.-B. Kim 2005, p. 165). Additionally, Kim notes that other relevant elements include: oneness between the human body or community and the land; harmonious and holistic life with humans promoting the common life of all living beings in the land; and the land as the basis of life, bearer of life's wisdom and spiritual reality. Thus, as a result of these understandings, land reform can be understood as a spiritual practice, according to Y.-B. Kim (2005, p. 168). Land reform proposals from the 17th century onwards emphasized justice for the poor or masses (i.e., the Minjung) against foreign or domestic oppression (Y.-B. Kim 2005, p. 170). Korean Christianity has drawn upon this understanding, by identifying with the Hebrew people in the scripture and superimposing it upon the Korean land by claiming it as promised, and seeking the liberation of both people and land in the context of oppression (Y.-B. Kim 2005, p. 165). Thus, Y.-B. Kim (2005, p. 179) argues for an Asian theology of the land informed by these understandings, and for an Asian theology of life based in understanding Jesus as the life of the cosmos. This is in direct response to reductionist economic policy as well as the land's exploitation, degradation and pollution by foreign and domestic powers. Thus, this paper asserts that these land-based understandings hold significant potential for informing a South Korean ecotheology and praxis in address of the climate crisis.

Specific to the Japanese case, Shintoism brings another distinct contribution. Shintoism can be considered as the indigenous religious-philosophical tradition of Japan, however, is arguably today considered its national ideology, strongly interconnected into society and culture, rather than only a religion (Chang and Kalmanson 2011, p. 223; Josephson 2012, p. 94; Parkes 1997, p. 113; Rots 2017, p. 25). It is most closely associated with Buddhism, although also incorporates some Confucian ideology (Chang and Kalmanson 2011, p. 223; Josephson 2012, p. 98; Nelson 2000, p. 10; Parkes 1997, p. 113; Rots 2017, p. 25). Shintoism is diverse and under continual reconstruction, as seen through Rots (2017, p. 29) articulation of six essentialist Shinto paradigms: imperial, ethnic, universal, local, spiritual and environmentalist (Josephson 2012, p. 97; Nelson 2000, p. 7; Rots 2017, p. 29). The ideas most relevant here are its environmental sensibilities; its understanding of nature as dwelling places of deities, as seen within the Kami and sacred shrine forest; its understanding of harmonious co-existence due to a oneness or equality between humanity and the natural environment as the offspring of the divine (Nelson 2000, p. 54; Parkes 1997, p. 113; Rots 2017, p. 65). Importantly, the interactions between Shinto mythology, Japanese nationalism and belief in spontaneous human virtue, and environmental sensibilities developed into the cultural notion of the Japanese "love of nature". Particularly the concept of "mono no aware" became central to Japan's "cultural-nationalist" argument in pursuit of solutions to ecological challenges within the Japanese tradition (Rots 2017, p. 59). Rots (2017, p. 60) argues that the Japanese "love of nature" became a trope, which is easily countered by noting Japan's domestic and international ecologically destructive activities. As such, Rots (2017, p. 72) suggests that a return to ancient Shinto values can provide solutions to ecological challenges. However, undoubtedly, Shintoism is closely interconnected with Japanese society and culture, an argument further supported through empirical examination of shrine practitioners (Nelson 2000, p. 22); popular culture's emphasis on the relationship between nature and Shinto shrines (Rots 2017, p. 81); as well as Shinto's ubiquitous socio-cultural role in response to Japan's substantial societal change (Nelson 2000, p. 3). Given Shintoism's close interconnection with Japanese society and culture, this paper asserts that it holds potential for informing a Japanese ecotheology and praxis in address of the climate crisis and therefore encourages engagement with ecological understandings and practices of Japanese society and culture broadly that are implicitly Shinto-influenced, rather than with Shintoism's institutions, clerics and scholars directly.

In the Chinese case, public religion brings a distinct contribution via the unique relationship between government and religion in China. Currently, according to Chow (2018, p. 8), the Chinese government allows freedom of religious belief (a private matter) but not freedom of religion (a public 
matter) and therefore any praxis-oriented ecotheology arguably must engage with the Chinese political system. Christianity has a long history of engagement in Chinese public space alongside other traditions. Thus, despite its current minority status and the challenges of the past sixty years, Chinese contextual theologizing has nonetheless demonstrated a capacity to work with the communist government for mutual benefit. The contextualization of Chinese theology and engagement in transnational Christian networks are noted as being key to governmental favor (Chow 2018, p. 117; Kaiser 2015; Ng 2011, p. 63; Yung 2004). Indeed, Chow (2018, p. 131) suggests that the challenge faced by Chinese Christianity in the public space is not its political constraints, but rather, theologically conservative traditions of Christianity resisting this contextualization. Further, given its Confucian influence, he argues that Chinese theology must learn to indeed engage in the public space (Chow 2018, p. 133). As such, this paper suggests that a Chinese ecotheology might seek to embrace Bishop Ting's commitment to developing a "Christianity with Chinese socialist characteristics" (Ng 2011, p. 60) through seeking to fulfil both its Chinese duty of "Loving the country" and Christian duty of "Loving the church". Any transnational Christian network must be bicultural to support the flourishing of the Chinese church and undertake any ecological praxis (Ng 2011, p. 69). Here, precedent exists within the Chinese public space, in the work of Chow and Bishop Ting (Chow 2018, p. 146; Ng 2011, p. 68). The Christian-Confucian dialogue noted earlier opens substantial opportunity for contextual ecotheologies, given the government's recent demonstrated support for New Confucianism and its preference to draw upon traditional Chinese culture, albeit interpreted through its nationalistic agenda (Chow 2018, p. 125; J. Miller 2013, p. 254, Ng 2011, p. 68). Therefore, this paper asserts that a Chinese ecotheology must seek to engage in religious-philosophical and socialist contextualization. As such, the Chinese public space not only necessarily shapes but also holds potential to inform a Chinese ecotheology in the climate crisis.

\section{Suggestion Toward East Asian Contextual Ecotheological Praxis}

This paper has sought to recognize the contours of what is already an emerging conversation rich with opportunity for continued theologizing, inter-religious and secular dialogue and practical impetus for East Asian Christians to mobilize in address of the climate crisis. Some contextually informed ecotheological suggestions are now proposed, that draw upon the resources above to recognize shared values in the region and link these with accessible actions. In this way, contextual understandings and practices for East Asian Christians both within and across China, South Korea and Japan may be brought forward into praxis.

The first underlying value identified from the study above is the importance of collaborative community conversation that represents the diversity, intersectionality and complexity of the region. As the church in East Asia plays a minority role, any truly effective action undertaken is likely to emerge from a dialogue that represents the community's diversity. Therefore, the recommendation is for the curation of various platforms for collaborative community conversation and development of civil engagement around ecologically beneficial practices. These conversations should be undertaken by people representative of the diversity, intersectionality and complexity of these local contexts, which may provide room for unexpected commonalities to be found and thus facilitate translation of ecotheologies. Discussion platforms may create benefits for community engagement and development, and have great potential to harness a collaborative civil society in address of the climate crisis. The capacity for local differentiation within platforms is also recommended, which may encourage further contextualization of ecotheologies and enable action contextual to specific local, national and transborder locations. It is beneficial for East Asian Christians (and the East Asian church) to cultivate space for interfaith ecotheological dialogue. However, such a dialogue needs to be inclusive not only of scholarly/theological or celebrity pastor/clerical voices but to include those representative of the scientific communities as well as the diverse local and regional interfaith communities as noted above. Ideally, such a platform would also enable space for each faith community to develop its own ecological ethic in address of the climate crisis, and to creatively transform its ethical tradition, as recommended 
by Lai (2014, p. 93). There is approximate precedent in examples of collaborative civil society engaging in dialogue, problem-solving, crowdfunding, and project, community or individual practical actions, e.g., Open IDEO (IDEO 2019), Global Citizen (Global Poverty Project, Inc. 2019), UpEffect (2020) and StartSomeGood (2019). Thus, the creation of a platform for dialogue is considered the first appropriate suggested action.

Additionally, this paper proposes the legally enshrined protection of urban, peri-urban and rural sites with local and national religious-philosophical, cultural, political and ecological significance. The literature asserts that there are often (direct and indirect) economic benefits to such ecologically beneficial initiatives as well as positive climate mitigation or adaptation impacts (Balmford et al. 2009; Pan et al. 2011; Day et al. 2010; Duperon 2017; Lee and Minato 2015; J. Miller 2013; Paracka 2012, p. 92; van Dijk 2011). Therefore, it is recommended that cross-denominational East Asian Christians support the establishment of such sites politically, where appropriate, and then through participation, engagement and consumption, as applicable. Earlier in the paper, it was noted that Buddhism has forged a beneficial presence within the economic sphere of East Asian society (Lancaster 1997, p. 9). This precedent creates opportunity for faith communities to argue for protections on the basis of their contributions, and with this rationale to seek out (and promote the consumption of) ecologically sustainable activities, products and services. Along with the dialogue platforms recommended above, this paper therefore recommends urban East Asian Christians establish and participate in initiatives such as urban farming and urban gardens with their interfaith neighbors. Such activities are likely to provide ecological benefits, such as strengthening urban food security and the health of local residents. As local communities develop interconnections, this results in civil society which often particularly benefits the vulnerable, as it supports economic revitalization and activity in lower socioeconomic urban communities (Arathi et al. 2018; Credit et al. 2017; Furness and Gallaher 2018; Hashim 2015; Neff et al. 2017).

The formation of a contextual East Asian theology necessitates the examination of the current ethic of consumption in operation in this region. In this way, any dialogue between diverse parties and the deepening of civil society allows for the identification of problematic theologies which may have prevented undertaking ecologically beneficial practices. Due to space, theologies that may prevent such work are not reviewed within this paper. However, dialogue would allow for the reflection or critical examination upon and revision of such theologies (including those relevant to prosperity) as relevant within East Asian Christianity. This is true for the Christian community, but also the wider interfaith community. As has been noted, East Asian consumption was formed in a particular way and therefore dialogue is likely to result in greater understanding of and engagement with the region's unique and complex cultural and socioeconomic pressures and aspirations. There is need for a continuing evaluation of how religious-philosophical understandings are interconnected in this picture. This paper proposes that interfaith dialogue be conducted with the end in mind of the development of an East Asian theology or ethic of consumption which results in more sustainable practice amongst East Asian Christians, as well as those of other/no faith.

Another contextually-informed ecotheological suggestion, based in a key underlying value identified within the region's resources, is the mutually beneficial interconnectedness or interrelationship between humanity and the natural world in which it lives. This desire for a harmonious existence encompasses the person within the household, and moves outwards into their communities, society, the wider human race and natural world. Therefore, the suggestion is that this value of appreciation for the natural world be developed further in religious-philosophical, cultural and social terms, rather than only economic and political terms in order for cross-denominational Christians to practice and encourage numerous individual and household actions in address of the climate crisis. Select examples of such actions include intentional awareness-raising for the climate crisis but also actions to address the climate crisis including: low energy retrofit of homes, use of renewable resources rather than non-renewable resources where possible, a shift to more sustainable consumption habits including fashion and dietary choices, increased recycling, decreased waste going to landfill, increased 
use of public transport and so on (Ellen MacArthur Foundation 2017; FAO 2013, p. 1; 2019; Global Fashion Agenda and The Boston Consulting Group 2017; IPCC 2014, p. 100; 2018b, p. 14; 2019b, p. 4; UN Environment 2016, p. 59). Given Bak's (2018) conclusion that people are more likely to engage in ecologically beneficial actions as a result of their perception of global rather than local ecological conditions, amplifying awareness of the global climate crisis is recommended. This may be more effective for engagement than amplifying local ecological issues. This paper strongly recommends cross-denominational Christians to practice appreciation of the natural world in religious-philosophical, cultural and social rather than economic terms.

The final contextually informed ecotheological suggestion this paper makes is an attempt to build upon the region's underlying value of pluralism. In response to this underlying value, this paper proposes differentiated actions particular to each case which may, nonetheless, find applicability across East Asia. The South Korean ecotheology's recognition of mountain sites alongside its syncretistic traditional understanding(s) of the land arguably may connect well with a shared East Asian recognition of mountain sites and foster ecological understandings across these groups. Therefore, actions could include the protection and appreciation of mountain sites and other natural places across East Asia in religious-philosophical, cultural and social terms, as related to the earlier proposals. Alternatively, Japanese ecotheology's engagement may connect with Shinto understandings via Japanese society and culture more broadly than with Shintoism's clerics, institutions and scholars, for more effective or tangible interfaith connections and ecological impact, due to the difficulty in determining the connection between one's religious-philosophical worldview and actual behavior. Instead, cues may be drawn from cultural demands, but particularly consumerist culture, and desire for self-wellbeing, which often supersedes any reverence for the natural environment (Parkes 1997, p. 112). Applied across East Asia, this may result in more effective engagement between interfaith and secular neighbors including East Asian cross-denominational Christians for mobilization in address of the climate crisis. Therefore, actions could include promotion, creation and support of and engagement with societal and cultural texts, trends, persons, groups, organizations and practices across East Asia that promote ecologically beneficial values and actions, particularly those which directly address the climate crisis.

\section{Conclusions}

This paper addressed the question "How might East Asian ecotheologies offer East Asian Christians a contextual theological basis with which to mobilize in address of the climate crisis?" This proposal does not aim to be comprehensive or definitive, but to scope the literature for possible resources that may assist East Asian Christians and those working in the region. ${ }^{6}$ This paper strongly encourages future scholarship, but particularly from within the East Asian context, to examine and develop East Asian ecotheology and its contextual practices for East Asian Christians to mobilize in address of the climate crisis. Indeed, there is ample space for such proposals.

This paper critically considered the significance of the East Asian region in relation to the climate crisis before summarizing contemporary ecotheologies, even while arguing for greater contextualization in this field. It critically evaluated some key elements to inform a contextual East Asian ecotheology. It is recognized that while the region does contribute significantly to the climate crisis, also concurrently ecologically beneficial practices are being undertaken, and the region is highly vulnerable to effects of the crisis. Of the demographic, socioeconomic, cultural, economic, political and ecological elements reviewed, there were a number relevant in informing East Asian ecotheology and a following praxis in address of the climate crisis. The interconnection between diverse socioeconomic, political, economic and ecological contextual elements is clear, with this paper suggesting the need for East Asian ecotheology and praxis to be deeply embedded to enable greater relevance and effectiveness of

6 As noted earlier in this paper, one of its limitations is that it is written from a non-East Asian perspective and within a Western context. 
understandings and practices. Opportunity exists for civil society to align individual practices and to lobby for ecologically beneficial and differentiated government agendas and efforts via an East Asian ecotheology. One demographic feature that was highlighted was the proportionately higher number of East Asian (particularly young) women and their demonstrated leadership and activism capacity. The contribution of this group towards transborder civil society collaboration is significant, which is important given the region's tendency to tension and dispute. The paper suggested that a shared East Asian ecotheology would also strongly benefit by enabling space for national case-based differentiation. It therefore imagined how East Asian ecotheologies might offer contextual understandings and practices within the subcontexts: three suggestions were made to assist East Asian Christians within the climate crisis. It concluded that there is ample space for a plurality of East Asian ecotheologies and alternate praxis of those ecotheologies.

This paper has proposed values underlying this paper's prior contextually informed ecotheological suggestions, and from these values, proposed practices through simple and accessible actions that might be appropriate for East Asian Christians to mobilize in address of the climate crisis. Additional actions could be provided or these actions further explored, however, due to the constraints of this paper, the above proposals are provided as sufficient examples.

Author Contributions: A.K.-J. designed the study and implemented it during her Masters degree. T.R. reviewed the design and its implementation as chair of the Research Committee. Both authors adapted this article and edited the manuscript to fit the journal's specifications. All authors have read and agreed to the published version of the manuscript.

Funding: This research received no external funding.

Conflicts of Interest: No conflict of interest to be noted.

\section{References}

Agyarko, Rober Owusu. 2013. God of Life. Rethinking the Akan Christian Concept of God in the Light of the Ecological Crisis. The Ecumenical Review 65: 51-66. [CrossRef]

Ahern, Annette. 2006. Preservation by "Letting Go": Buddhist Impermanence (Anicca) in Ruether's Ecotheology. Ecotheology 11: 212-32. [CrossRef]

Ahn, Illsup. 2015. From Colonising Contract to Decolonizing Covenant. The Case for Ecological Justice in Maquiladoras and a New Covenantal Approach to Christian Environmental Ethics. Cross Currents 65: 30-56. [CrossRef]

Anderson, Allan H. 2000. Pentecostalism in East Asia: Indigenous Oriental Christianity? Pneuma: The Journal of the Society for Pentecostal Studies 22: 115-32. [CrossRef]

Anker, Peder. 2013. The Call for a New Ecotheology in Norway. Journal for the Study of Religion, Nature and Culture 7: 187-207. [CrossRef]

Arathi, Seshadri, Cynthia S. Brown, Michael Carolan, Becca B. R. Jablonski, Erin Lapansky, Starin McKeen, Theresa Nogeire-McRae, Elizabeth Ryan, Hairik Honarchian Saki, and Meagan E. Schipanski. 2018. The Role of Urban Agriculture in a Secure, Healthy, and Sustainable Food System. BioScience 68: 748-59.

Assmann, Stephanie. 2018. Consumption of Fast Fashion in Japan. Local Brands and Global Environment. In Consuming Life in Post-Bubble Japan: A Transdisciplinary Perspective. Edited by Katarzyna J. Cwiertka and Ewa Machotka. Amsterdam: Amsterdam University Press, pp. 49-68.

Awad, Simon I. 2016. Advocacy for Eco-Justice in Palestine. In Making Peace with the Earth. Action and Advocacy for Climate Justice. Edited by Grace Ji-Sun Kim. Geneva: WCC Publications, pp. 52-68.

Bae, Yooil. 2013. Decentralized Urban Governance and Environmental Collaboration in South Korea: The Case of Hyundai City. Pacific Affairs 86: 759-83. [CrossRef]

Bak, Hee-Je. 2018. Thinking Globally and Acting Locally? Geographical Dimension of Environmental Concern as Predictors of Pro-Environmental Behaviors. Development and Society 47: 587-612.

Balabanski, Vicky. 2008. Critiquing "Anthropocentric Cosmology": Retrieving a Stoic "Permeation Cosmology" in Colossians 1:15-20. In Exploring Ecological Hermeneutics. Edited by Norman C. Habel and Peter Trudinger. Society of Biblical Literature 46. Atlanta: Society of Biblical Literature, pp. 151-59. 
Balmford, Andrew, James Beresford, Jonathan Green, Andrea Manica, Robin Naidoo, and Matt Walpole. 2009. A Global Perspective on Trends in Nature-Based Tourism. PLoS Biology 7: 1-6. [CrossRef]

Barrett, Peter. 2013. Theology in the Context of Science-Western and African Aspects. Journal of Theology for Southern Africa 147: 31-50.

Bauckham, Richard. 1998. Scripture and Authority. Transformation 15: 5-11.

Berry, Thomas. 2003. The New Story. In Teilhard in the 21st Century: The Emerging Spirit of the Earth. Edited by Arthur Fabel and Donald St. John. Maryknoll: Orbis Books, pp. 77-88.

Bevans, Stephen B. 2002. Models of Contextual Theology, Revised and Expanded ed. Faith and Cultures Series; Maryknoll: Orbis Books.

Bock, Cherice. 2016. Climatologists, Theologians, and Prophets: Towards an Ecotheology of Critical Hope. Cross Currents 66: 8-34.

Boff, Leonardo. 1997. Cry of the Earth, Cry of the Poor. Maryknoll: Orbis Books.

Chang, Wonsuk, and Leah Kalmanson, eds. 2011. Confucianism in Context: Classic Philosophy and Contemporary Issues, East Asia and Beyond. UNY Series in Chinese Philosophy and Culture; Albany: State University of New York Press.

Choe, Hyeyeong, James H. Thorne, Patrick R. Huber, Dongkun Lee, and James F. Quinn. 2018. Assessing Shortfalls and Complementary Conservation Areas for National Plant Biodiversity in South Korea. PLoS ONE 13. [CrossRef]

Chow, Alexander. 2018. Chinese Public Theology: Generational Shifts and Confucian Imagination in Chinese Christianity. Oxford: Oxford University Press.

Chun, Young-Min., Tak Ki-Hong, and Wood Paul M. 2007. The South Korean Forest Dilemma. The International Forestry Review 9: 548-57.

Chung, Dai-Wi. 2010. Christianity and the Religious World of East Asians. The Principle of Three Religions as One. In Asian Contextual Theology for the Third Millennium: Theology of Minjung in Fourth-Eye Formation. Edited by Paul S. Chung, Veli-Matti Kärkkäinen and Kyoung-Jae Kim. Translated by Paul S. Chung. Cambridge: James Clarke \& Co Ltd., pp. 269-83.

Chung, Meehyun. 2016. Rice Is Heaven. Revisiting and Transforming Lost Korean Values in the Era of Climate Change. In Making Peace with the Earth. Action and Advocacy for Climate Justice. Edited by Grace Ji-Sun Kim. Geneva: WCC Publications, pp. 165-80.

Chung, Jae Ho, and Jiyoon Kim. 2016. Is South Korea in China's Orbit? Assessing Seoul's Perceptions and Policies. Asia Policy 21: 123-46.

Clough, David L. 2012. On Animals. Volume 1 Systematic Theology. London: Bloomsbury T\&T Clark.

Clough, David L. 2019. On Animals. Volume 2 Theological Ethics. Edinburgh: T\&T Clark.

Conradie, Ernst M. 2009. Towards a Theology of Place in the South African Context: Some Reflections from the Perspective of Ecotheology. Religion \& Theology 16: 3-18.

Credit, Kevin, Elizabeth A. Mack, and Daoqin Tong. 2017. Gardening in the Desert: A Spatial Optimization Approach to Locating Gardens in Rapidly Expanding Urban Environments. International Journal of Health Geographics 16: 1-16.

Day, Brett, Agusto Dueñas-Dueñas, Renzo Giudice-Granados, Christopher A. Kirkby, Juan Carlos Lara-Rivas, Kerry Turner, Luz Marina Velarde-Andrade, and Douglas W. Yu. 2010. The Market Triumph of Ecotourism: An Economic Investigation of the Private and Social Benefits of Competing Land Uses in the Peruvian Amazon. PLOS ONE 5: 1-14.

Deane-Drummond, Celia. 2008. Eco-Theology. London: Darton, Longman \& Todd Ltd.

Diamond, Joan, Peter Hayes, and Kiho Yi. 2015. Anticipating Complex Northeast Asian Futures. In Complexity, Security and Civil Society in East Asia: Foreign Policies and the Korean Peninsula. Edited by Peter Hayes and Kiho Yi. Cambridge: Open Book Publishers, pp. 393-408.

Duperon, Matthew. 2017. Solving for the Triad: Xunzi and Wendell Berry on Sustainable Agriculture as Ethical Practice. Philosophy East and West 67: 380-98.

Ellen MacArthur Foundation. 2017. A New Textiles Economy: Resdesigning Fashion's Future. Cowes: Ellen MacArthur Foundation.

Erickson, Millard J. 2013. Christian Theology, 3rd ed. Grand Rapids: Baker Academic.

FAO. 2013. Tackling Climate Change Through Livestock: A Global Assessment of Emissions and Mitigation Opportunities. Rome: Food and Agriculture Organization of the United Nations (FAO). 
FAO. 2019. Livestock and the Environment. Food and Agriculture Organization of the United Nations. Available online: http://www.fao.org/livestock-environment/en/ (accessed on 24 August 2019).

Feldman, Hannah. 2019. Young People Won't Accept Inaction on Climate Change, and They'll Be Voting in Droves. The Conversation. May 3. Available online: https://theconversation.com/young-people-wont-acceptinaction-on-climate-change-and-theyll-be-voting-in-droves-116442 (accessed on 4 December 2019).

Flannery, Tim. 2019. The Gloves Are off: "Predatory" Climate Deniers Are a Threat to Our Children. The Conversation. September 17. Available online: https://theconversation.com/the-gloves-are-off-predatoryclimate-deniers-are-a-threat-to-our-children-123594 (accessed on 4 December 2019).

Fox, Matthew. 1988. The Coming of the Cosmic Christ. The Healing of Mother Earth and the Birth of a Global Renaissance. New York: Harper \& Row.

Furness, Walter W., and Courtney M. Gallaher. 2018. Food Access, Food Security and Community Gardens in Rockford, IL. Local Environment 23: 414-30.

Global Fashion Agenda, and The Boston Consulting Group. 2017. Pulse of the Fashion Industry. Copenhagen and Boston: Global Fashion Agenda \& The Boston Consulting Group.

Global Poverty Project, Inc. 2019. Global Citizen. Available online: https://www.globalcitizen.org/en/au/ (accessed on 1 December 2019).

Grant, Maria J., and Andrew Booth. 2009. A Typology of Reviews: An Analysis of 14 Review Types and Associated Methodologies. Health Info Libraries Journal 26: 91-108.

Green, Emma. 2014. Half of Americans Think Climate Change Is a Sign of the Apocalypse. The Atlantic. November 22. Available online: https://www.theatlantic.com/politics/archive/2014/11/half-of-americans-think-climatechange-is-a-sign-of-the-apocalypse/383029/ (accessed on 3 December 2019).

Grenz, Stanley J. 2000. Theology for the Community of God. Grand Rapids: William B. Eerdmans Publishing Company.

Habel, Norman C. 2008. Introducing Ecological Hermeneutics. In Exploring Ecological Hermeneutics. Edited by Norman C. Habel and Peter Trudinger. Society of Biblical Literature 46. Atlanta: Society of Biblical Literature, pp. 1-8.

Habito, Ruben L. F. 2003. Japanese Buddhist Perspectives and Comparative Theology- Supreme Ways in Intersection. Theological Studies 64: 362-87.

Hashim, Nadra. 2015. Reversing Food Desertification: Examining Urban Farming in Louisville, Chicago and Detroit. Local Environment 20: 611-36.

Hertsgaard, Mark. 1997. Our Real China Problem. The Atlantic Monthly. November. Available online: https://www. theatlantic.com/magazine/archive/1997/11/our-real-china-problem/376989/ (accessed on 22 October 2019).

Holtzen, Wm. Curtis, and Matthew Nelson Hill. 2016. Gadamer's Hermeneutic of Trust-Ontological and Reflective. In In Spirit and in Truth: Philosophical Reflections on Liturgy and Worship. Edited by Wm. Curtis Holtzen and Matthew Nelson Hill. Claremont: Claremont Press, pp. 87-108.

Hong, In Sik. 2013. God of Life, Lead Us to Justice and Peace: Reflection from an Asian and Korean Church Perspective. International Review of Mission 102: 56-68.

Howard, Cameron B. R. 2008. Animal Speech as Revelation in Genesis 3 and Numbers 22. In Exploring Ecological Hermeneutics. Edited by Norman C. Habel and Peter Trudinger. Society of Biblical Literature 46. Atlanta: Society of Biblical Literature, pp. 21-29.

Hwang, Jae-Buhm. 2007. A New Confession of Faith with an Eco-Theology and a Father-Centred Trinitarianism: A Critical Study of the 21st Century Confession of Faith of the Presbyterian Church of Korea. International Review of Mission 96: 128-41.

IDEO. 2019. OpenIDEO. Available online: https://www.openideo.com/ (accessed on 1 December 2019).

IPCC. 2014. Climate Change 2014: Synthesis Report. Contribution of Working Groups I, II and III to the Fifth Assessment Report of the Intergovernmental Panel on Climate Change. Geneva: IPCC.

IPCC. 2018a. Global Warming of $1.5^{\circ} \mathrm{C}$. An IPCC Special Report on the Impacts of Global Warming of $1.5^{\circ} \mathrm{C}$ above Pre-Industrial Levels and Related Global Greenhouse Gas Emission Pathways, in the Context of Strengthening the Global Response to the Threat of Climate Change, Sustainable Development, and Efforts to Eradicate Poverty. Geneva: IPCC.

IPCC. 2018b. Summary for Policymakers-Global Warming of $1.5^{\circ} \mathrm{C}$. An IPCC Special Report on the Impacts of Global Warming of $1.5^{\circ} \mathrm{C}$ above Pre-Industrial Levels and Related Global Greenhouse Gas Emission Pathways, in the Context of Strengthening the Global Response to the Threat of Climate Change, Sustainable Development, and Efforts to Eradicate Poverty. Geneva: IPCC. 
IPCC. 2019a. Chapter 1: Framing and Context-Climate Change and Land. An IPCC Special Report on Climate Change, Desertification, Land Degradation, Sustainable Land Management, Food Security, and Greenhouse Gas Fluxes in Terrestrial Ecosystems. Geneva: IPCC.

IPCC. 2019b. Summary for Policymakers-Climate Change and Land. An IPCC Special Report on Climate Change, Desertification, Land Degradation, Sustainable Land Management, Food Security, and Greenhouse Gas Fluxes in Terrestrial Ecosystems. Geneva: IPCC.

Jenkins, Willis, Evan Berry, and Luke Beck Kreider. 2018. Religion and Climate Change. Annual Review of Environment and Resources 43: 85-108.

John, Arit. 2014. Faith Leaders Prove It's Possible to Believe in God and Climate Change. The Atlantic. July 30. Available online: https://www.theatlantic.com/politics/archive/2014/07/faith-leaders-prove-its-possible-tobelieve-in-god-and-climate-change/375328/ (accessed on 3 December 2019).

Joo, Yunjeong. 2018. Same Despair but Different Hope: Youth Activism in East Asia and Contentious Politics. Development and Society 47: 401-22.

Josephson, Jason Ānanda. 2012. The Invention of Religion in Japan. Chicago: University of Chicago Press.

Kaiser, Sigurd. 2015. Church Growth in China: Some Observations from an Ecumenical Perspective. The Ecumenical Review 67: 35-47.

Kalton, Michael C. 2011. Confucian Trajectories on Environmental Understanding. In Confucianism in Context: Classic Philosophy and Contemporary Issues, East Asia and Beyond. Edited by Wonsuk Chang and Leah Kalmanson. SUNY Series in Chinese Philosophy and Culture; Albany: State University of New York Press, pp. 191-209.

Kärkkäinen, Veli-Matti. 2002. Pneumatology: The Holy Spirit in Ecumenical, International, and Contextual Perspective. Grand Rapids: Baker Academic.

Kärkkäinen, Veli-Matti. 2003. Christology: A Global Introduction. Grand Rapids: Baker Academic.

Kärkkäinen, Veli-Matti. 2004. The Doctrine of God: A Global Introduction. Grand Rapids: Baker Academic.

Kim, Yong-Bok. 2005. The Land as the Garden of Life. Studies in World Christianity 11: 165-81.

Kim, Kyoung-Jae. 2010. A Conception of an Ecological Theology of Spirit and Ch'i. In Asian Contextual Theology for the Third Millennium: Theology of Minjung in Fourth-Eye Formation. Edited by Paul S. Chung, Veli-Matti Kärkkäinen and Kyoung-Jae Kim. Translated by Paul S. Chung. Cambridge: James Clarke \& Co Ltd., pp. $285-302$.

Kim, Heup Young. 2017. A Theology of Dao. Maryknoll: Orbis Books.

Kjellberg, Seppo. 2004. Eino and Elisa: Contextual Christianity Discusses Urban Sustainability. Ecotheology 9: 49-64.

Kracher, Alfred. 2000. Stories and Theories: A Scientific Challenge to Theology. Zygon: Journal of Religion E Science 35: 481-87.

Kwan, Simon Shui-Man. 2014. Postcolonial Resistance and Asian Theology. Routledge Studies in Asian Religion and Philosophy. Abingdon: Routledge.

Kwara, Timothy. 2014. Towards an Ecotheology for PNG-Relating Biblical Environmental Stewardship with the Melanesian Cultural Concept of Inseparability and Interrelatedness of Humankind and Nature. Melanesian Journal of Theology 30: 43-73.

Lai, Pan-Chiu. 2004. The Doctrines of the Trinity and Christology and Hua-Yen Buddhism. Ching Feng, English Edition 5: 203-25.

Lai, Pan-Chiu. 2006. The Kingdom of God and the Pure Land: A Dialogical Study of Eschatology and Praxis. Ching Feng 7: 183-210.

Lai, Pan-Chiu. 2014. Inter-Religious Dialogue on Ecology: A View from China. Religions 4: 82-97.

Lam, Jason. 2013. Theological Reflection on the Ecological Problem in Relation to the Accra Confession: An East Asian Perspective. International Review of Mission 102: 220-35.

Lancaster, Lewis. 1997. Buddhism and Ecology: Collective Cultural Perceptions. In Buddhism and Ecology. The Interconnection of Dharma and Deeds. Edited by Mary Evelyn Tucker and Duncan Ryūken Williams. Religions of the World and Ecology Series; Cambridge: Harvard University Press, pp. 3-18.

Lee, Sanghun, and Takayuki Minato. 2015. Urban Security and Complexity in Northeast Asia. In Complexity, Security and Civil Society in East Asia. Foreign Policies and the Korean Peninsula. Edited by Peter Hayes and Kiho Yi. Cambridge: Open Book Publishers, pp. 223-60.

Liu, JeeLoo. 2006. An Introduction to Chinese Philosophy: From Ancient Philosophy to Chinese Buddhism. Carlton: Blackwell Publishing. 
Lugazia, Faith K. 2016. The Holy Spirit, Eco-Justice, and an African Lutheran Response to Ecological Peril. Dialog: A Journal of Theology 55: 282-86.

Marlow, Hilary. 2008. The Other Prophet! The Voice of the Earth in the Book of Amos. In Exploring Ecological Hermeneutics. Edited by Norman C. Habel and Peter Trudinger. Society of Biblical Literature 46. Atlanta: Society of Biblical Literature, pp. 75-83.

Mcateer, Michael. 2012. Japan's Latest Nuclear Crisis: Getting Rid of the Radioactive Debris. The Atlantic. June 4. Available online: https:/www.theatlantic.com/international/archive/2012/06/japans-latest-nuclear-crisisgetting-rid-of-the-radioactive-debris/257963/ (accessed on 22 October 2019).

Migliore, Daniel L. 2014. Faith Seeking Understanding: An Introduction to Christian Theology, 3rd ed. Grand Rapids: Eerdmans Publishing.

Miller, Susan. 2008. The Descent of Darkness over the Land: Listening to the Voice of the Earth in Mark 15:33. In Exploring Ecological Hermeneutics. Edited by Norman C. Habel and Peter Trudinger. Society of Biblical Literature 46. Atlanta: Society of Biblical Literature, pp. 123-30.

Miller, James. 2013. Is Green the New Red? The Role of Religion in Creating a Sustainable China. Nature and Culture 8: 249-64.

Moltmann, Jürgen. 1993a. God in Creation: A New Theology of Creation and the Spirit of God. Translated by Margaret Kohl. Minneapolis: Fortress Press.

Moltmann, Jürgen. 1993b. The Trinity and the Kingdom: The Doctrine of God. Translated by Margaret Kohl. Minneapolis: Fortress Press.

Moltmann, Jürgen. 1993c. The Way of Jesus Christ. Christology in Messianic Dimensions. Translated by Margaret Kohl. Minneapolis: Fortress Press.

Moltmann, Jürgen. 2000. Experiences in Theology: Ways and Forms of Christian Theology. Translated by Margaret Kohl. Minneapolis: Fortress Press.

Moltmann, Jürgen. 2012. Ethics of Hope. Translated by Margaret Kohl. Minneapolis: Fortress Press.

Neff, Roni A., Melissa N. Poulsen, and Peter J. Winch. 2017. The Multifunctionality of Urban Farming: Perceived Benefits for Neighbourhood Improvement. Local Environment 22: 1411-27.

Nelson, John K. 2000. Enduring Identities: The Guise of Shinto in Contemporary Japan. Honolulu: University of Hawaii Press.

Ng, Peter Tze Ming. 2011. Global Christianity and Local Contexts: The Case of K.H. Ting and the Three-Self Church in China. Exchange 40: 57-70.

Nwaigbo, Ferdinand. 2011. Jesus, Justice and Ecology: An African Perspective. AFER 53: 353-73.

O’Brien, Kevin J. 2012. La Causa and Environmental Justice: César Chávez as a Resource for Christian Ecological Ethics. Journal of the Society of Christian Ethics 32: 151-68.

Oh, Jae Sophia. 2016. Salim, Ever-Recycling Energy. A Korean Postcolonial Eco-Feminist Theology of Life. In Making Peace with the Earth. Action and Advocacy for Climate Justice. Edited by Grace Ji-Sun Kim. Geneva: WCC Publications, pp. 154-64.

Okonkwo, Izunna. 2011. Ecological Crises: From the Perspective of Christianity and African Traditional Religion. Journal of Theology for Southern Africa 141: 32-44.

Ormerod, Neil, and Shane Clifton. 2009. Globalization and the Mission of the Church. London: T\&T Clark.

Pan, Chenguang, Shuifa Ke, Yan Zheng, and Ying Zhang. 2011. The Multiplier Effect of the Development of Forest Park Tourism on Employment Creation in China. Journal of Employment Counseling 48: 136-44.

Pannenberg, Wolfhart. 1994a. Systematic Theology_Volume 2. Translated by Geoffrey W. Bromiley. Grand Rapids: William B. Eerdmans Publishing Company.

Pannenberg, Wolfhart. 1994b. Systematic Theology_Volume 3. Translated by Geoffrey W. Bromiley. Grand Rapids: William B. Eerdmans Publishing Company.

Paracka, Daniel J., Jr. 2012. China's Three Teachings and the Relationship of Heaven, Earth, and Humanity. Worldviews 16: 73-98.

Parkes, Graham. 1997. Voices of Mountains, Trees, and Rivers: Kūkai, Dōgen, and a Deeper Ecology. In Buddhism and Ecology. The Interconnection of Dharma and Deeds. Edited by Mary Evelyn Tucker and Duncan Ryūken Williams. Religions of the World and Ecology Series; Cambridge: Harvard University Press, pp. 111-28. 
Peterson, Matt. 2018. China's New Environmental Story. The Atlantic. December 17. Available online: https: //www.theatlantic.com/membership/archive/2018/12/chinas-new-environmental-story/578362/ (accessed on 22 October 2019).

Pew Research Center. 2019a. Buddhists. Pew-Templeton Global Religious Futures Project. Available online: http://www.globalreligiousfutures.org/religions/buddhists (accessed on 30 October 2019).

Pew Research Center. 2019b. Countries_Profiles_China. Pew-Templeton Global Religious Futures Project. Available online: http://www.globalreligiousfutures.org/countries/china\#/?affiliations_religion_id=0\&affiliations_year= 2050\&region_name=All\%20Countries\&restrictions_year=2016 (accessed on 22 August 2019).

Pew Research Center. 2019c. Countries_Profiles_Japan. Pew-Templeton Global Religious Futures Project. Available online: http://www.globalreligiousfutures.org/countries/japan\#/?affiliations_religion_id=0\&affiliations_year= 2010\&region_name=All\%20Countries\&restrictions_year=2016 (accessed on 22 August 2019). Pew-Templeton Global Religious Futures Project.

Pew Research Center. 2019d. Countries_Profiles—South Korea. Pew-Templeton Global Religious Futures Project. Available online: http://www.globalreligiousfutures.org/countries/south-korea\#/?affiliations_ religion_id=0\&affiliations_year=2010\&region_name=All\%20Countries\&restrictions_year=2016 (accessed on 22 August 2019). Pew-Templeton Global Religious Futures Project.

Rieger, Joerg. 2004. Re-Envisioning Ecotheology and the Divine from the Margins. Ecotheology 9: 65-85.

Roemer, Michael. 2009. Religious Affiliation in Contemporary Japan: Untangling the Enigma. Review of Religious Research 50: 298-320.

Rots, Aike P. 2017. Shinto, Nature and Ideology in Contemporary Japan. Making Sacred Forests. Bloomsbury Shinto Studies. London: Bloomsbury Academic.

Schreiter, Robert J. 2015. Constructing Local Theologies, 30th Anniversary ed. Maryknoll: Orbis Books.

Schreurs, Miranda A. 2001. Women in Politics, Protecting the Environment in Northeast Asia. Journal of East Asian Studies 1: 63-92.

Scoville, Judith N. 2000. Leopold's Land Ethic and Ecotheology. Ecotheology 8: 58-70.

Spencer, Andrew J. 2015. Beyond Christian Environmentalism: Ecotheology as an Over-Contextualized Theology. Themelios 40: 414-28.

Sponberg, Alan. 1997. Green Buddhism and the Hierarchy of Compassion. In Buddhism and Ecology. The Interconnection of Dharma and Deeds. Edited by Mary Evelyn Tucker and Duncan Ryūken Williams. Religions of the World and Ecology Series; Cambridge: Harvard University Press, pp. 351-76.

StartSomeGood. 2019. StartSomeGood. Available online: https://startsomegood.com/ (accessed on 1 December 2019).

Swearer, Donald K. 2006. An Assessment of Buddhist Eco-Philosophy. Harvard Theological Review 99: 123-37.

Swenson, Kristin M. 2008. Earth Tells the Lessons of Cain. In Exploring Ecological Hermeneutics. Edited by Norman C. Habel and Peter Trudinger. Society of Biblical Literature 46. Atlanta: Society of Biblical Literature, pp. 31-39.

Tanchanpongs, Natee. 2015. Asian Reformulations of the Trinity: An Evaluation. In The Trinity among the Nations: The Doctrine of God in the Majority World. Edited by Gene L. Green, Stephen T. Pardue and K. K. Yeo. Majority World Theology Series; Grand Rapids: William B. Eerdmans Publishing Company, pp. 100-119.

Taylor, Alan. 2019a. Photos: Climate-Change Protests Around the World. The Atlantic. April 25. Available online: https://www.theatlantic.com/photo/2019/04/photos-climate-change-protests-around-world/588016/ (accessed on 4 December 2019).

Taylor, Alan. 2019b. Scenes from the Aftermath of Typhoon Hagibis in Japan. The Atlantic. October 15. Available online: https://www.theatlantic.com/photo/2019/10/scenes-aftermath-of-typhoon-hagibis/600040/ (accessed on 7 November 2019).

The Economist. 2010. China and India. Contest of the Century. The Economist. August 19. Available online: https://www.economist.com/leaders/2010/08/19/contest-of-the-century (accessed on 22 October 2019).

The Economist. 2012. The Asian-Pacific Future. It's Australian for "Asian Century". The Economist. October 31. Available online: https://www.economist.com/banyan/2012/10/31/its-australian-for-asian-century (accessed on 3 November 2019).

The Economist. 2018. A New Hegemon. The Chinese Century Is Well under Way. The Economist. October 27. Available online: https:/www.economist.com/graphic-detail/2018/10/27/the-chinese-century-is-well-underway (accessed on 22 October 2019). 
The Economist. 2019a. Banyan. Are Dictatorships Better than Democracies at Fighting Climate Change? The Economist. September 19. Available online: https://www.economist.com/asia/2019/09/19/are-dictatorshipsbetter-than-democracies-at-fighting-climate-change (accessed on 22 October 2019).

The Economist. 2019b. Pandas Can Fly. The Struggle to Reform China's Economy. The Economist. February 21. Available online: https://www.economist.com/leaders/2019/02/21/the-struggle-to-reform-chinas-economy (accessed on 22 October 2019).

The Economist. 2019c. The Global Centre. The Story of China's Economy as Told through the World's Biggest Building. The Economist. February. Available online: https://www.economist.com/essay/2019/02/23/the-storyof-chinas-economy-as-told-through-the-worlds-biggest-building (accessed on 22 October 2019).

The World Bank Group. 2019a. Population, Total. Available online: https://data.worldbank.org/indicator/SP.POP. TOTL (accessed on 24 August 2019).

The World Bank Group. 2019b. Total Greenhouse Gas Emissions (\% Change from 1990). Available online: https://data.worldbank.org/indicator/EN.ATM.GHGT.ZG?end=2012\&locations=CN-JP-KR\&start= 2012\&view=bar (accessed on 24 August 2019).

Troster, Lawrence. 2013. What Is Eco-Theology? Cross Currents 63: 380-85.

UN Environment. 2016. GEO-6 Regional Assessment for Asia and the Pacific. Nairobi: UN Environment Programme. UN Environment. 2019. GEO-6 For Industry in Asia-Pacific. Nairobi: UN Environment Programme.

United Nations. 2018. Goal 13 Climate Action-Take Urgent Action to Combat Climate Change and Its Impacts. United Nations-Sustainable Development Goals. Available online: https://www.un.org/sustainabledevelopment/ climate-change-2/ (accessed on 24 August 2019).

United Nations. 2019. Chapter XXVII Environment-7. d. Paris Agreement. United Nations-Treaty Collection. Available online: https://treaties.un.org/Pages/ViewDetails.aspx?src=IND\&mtdsg_no=XXVII-7-d\&chapter= 27\&clang=_en (accessed on 24 August 2019).

UpEffect. 2020. UpEffect. Available online: https://www.theupeffect.com/ (accessed on 6 July 2020).

van Dijk, Meine Pieter. 2011. Three Ecological Cities, Examples of Different Approaches in Asia and Europe. In Eco-City Planning. Policies, Practice and Design. Edited by Tai-Chee Wong and Belinda Yuen. Dordrecht: Springer, pp. 31-50.

Wacker, Grant. 2009. Heaven Below: Early Pentecostals and American Culture. Cambridge: Harvard University Press. Walraven, Boudewijn. 2009. National Pantheon, Regional Deities, Personal Spirits? Mushindo, Songsu, and the Nature of Korean Shamanism. Asian Ethnology 68: 55-80.

Weiming, Tu. 2001. The Ecological Turn in New Confucian Humanism: Implications for China and the World. Daedalus 130: 243-64.

Wolcott, Carrie Sinclair. 2016a. Feminist Biblical Hermeneutics. In The Lexham Bible Dictionary. Edited by John D. Barry, David Bomar, Derek R. Brown, Rachel Klippenstein, Douglas Mangum, Carrie Sinclair Wolcott, Lazarus Wentz, Elliot Ritzema and Wendy Widder. Bellingham: Lexham Press.

Wolcott, Carrie Sinclair. 2016b. Liberation Theologies and Hermeneutics. In The Lexham Bible Dictionary. Edited by John D. Barry, David Bomar, Derek R. Brown, Rachel Klippenstein, Douglas Mangum, Carrie Sinclair Wolcott, Lazarus Wentz, Elliot Ritzema and Wendy Widder. Bellingham: Lexham Press.

Xiangchen, Sun. 2010. A New Approach to Ecological Theology in the Frame of Confucian-Christian Dialogue: On Confucian-Christian Dialogue and Ecological Concern. Ching Feng 10: 179-88.

Yong, Amos. 2004. The Hermeneutical Trialectic: Notes toward a Consensual Hermeneutic and Theological Method. The Heythrop Journal 45: 22-39.

Yong, Amos. 2010. In the Days of Caesar: Pentecostalism and Political Theology: The Cadbury Lectures 2009. Sacra Doctrina: Christian Theology for a Postmodern Age. Grand Rapids: William B. Eerdmans Publishing Company.

Yung, Hwa. 2004. The Church in China Today. Transformation 21: 126-28. [CrossRef]

Zheng, Siqi, and Matthew E. Kahn. 2017. A New Era of Pollution Progress in Urban China? The Journal of Economic Perspectives 31: 71-92. [CrossRef]

Zhuang, Juzhong. 2017. How to Bring about the Asian Century. Asian Development Bank-Asian Development Blog. May 5. Available online: https://blogs.adb.org/blog/how-bring-about-asian-century (accessed on 24 August 2019).

(C) 2020 by the authors. Licensee MDPI, Basel, Switzerland. This article is an open access article distributed under the terms and conditions of the Creative Commons Attribution (CC BY) license (http://creativecommons.org/licenses/by/4.0/). 